\title{
REFLEXÕES A PARTIR DE REGISTROS DE PERCEPÇÕES DOS MBYA GUARANI SOBRE INTERCULTURALIDADE EM AÇÕES SOCIOAMBIENTAIS
}

BEATRIZ OSORIO STUMPF ${ }^{1}$

IECAM

DENISE ROSANA WOLF ${ }^{2}$

IECAM

PAULO ROBERTO MARQUES FERNANDES ${ }^{3}$

IECAM

VIRGINIA KOCH ${ }^{4}$

IECAM

RESUMO: $O$ artigo apresenta reflexões sobre interculturalidade em ações socioambientais com comunidades indígenas, a partir do registro de percepções mbya guarani sobre este tema. A investigação mostra a importância de culturas diversas estarem construindo ações em conjunto para atender às demandas das aldeias, se complementando, trocando ideias e experiências e enfrentando as dificuldades que fazem parte destes processos. O efeito é de complementaridade de saberes, com aprendizagens e transformações mútuas, mantendo o respeito à diversidade cultural. A sabedoria mbya guarani constitui um conjunto de saberes, valores e práticas que pode contribuir para transformações necessárias à nossa sociedade. Alguns conhecimentos e técnicas ecológicas ocidentais podem colaborar para resolver questões ambientais em suas áreas, sendo integrados aos seus modos de vida, respeitando seus tempos, ritmos, necessidades e interesses, junto a estímulos para a revitalização de atividades tradicionais. Para que isto ocorra, é necessário um contínuo exercício de valorização simétrica de conhecimentos, com a devida atenção para padrões hierárquicos fixados em nossa sociedade.

PALAVRAS-CHAVE: interculturalidade; ação socioambiental; interaprendizagem; educação indígena.

\footnotetext{
1 Mestra em Educação pela Universidade Federal do Rio Grande do Sul (UFRGS), Pedagoga pela Universidade Luterana do Brasil (ULBRA), Consultora do Instituto de Estudos Culturais e Ambientais (IECAM). E-mail: beatriz.osoriostumpf@yahoo.com.br.

2 Especialista em Gestão Ambiental pela Fundação Getúlio Vargas (FGV), Bióloga, Bacharel em Ecologia pela ULBRA, Presidente do IECAM. E-mail: denisewolf@terra.com.br.

${ }^{3}$ Graduado pelo Curso Superior em Desenvolvimento Rural (PLAGEDER) da UFRGS, Consultor do IECAM. E-mail: pr.120@ hotmail.com.

4 Mestra em Agronomia pela UFRGS, com Especialização em Ecologia Humana pela UNISINOS, Bióloga graduada pela UNISINOS, Consultora do IECAM. E-mail: virginia.para@ yahoo.com.br.
} 


\begin{abstract}
The article presents reflections on interculturality in social and environmental actions with indigenous communities, based on the Mbya Guarani perceptions record on this theme. Research shows the importance of diverse cultures building actions together to meet the demands of the villages, complementing each other, exchanging ideas and experiences and facing the difficulties that are part of these processes. The effect is of complementarity of knowledge, with learning and mutual transformations, while maintaining respect for cultural diversity. Mbya Guarani wisdom constitutes a set of knowledge, values and practices that can contribute to the necessary transformations in our society. Some western ecological knowledge and techniques can collaborate to solve environmental issues in their areas, being integrated with their ways of life, respecting their times, rhythms, needs and interests, along with stimuli for the revitalization of traditional activities. For this to occur, a continuous exercise of symmetrical appreciation of knowledge is necessary, with due attention to hierarchical patterns set in our society.
\end{abstract}

KEYWORDS: interculturality; socio-environmental action; interlearning; indigenous education.

\title{
Introdução
}

O artigo apresenta reflexões sobre interculturalidade em ações socioambientais com povos indígenas, a partir do registro de percepções mbya guarani sobre este tema, bem como debates entre profissionais de diversas áreas, durante pesquisa integrada ao desenvolvimento do projeto Ar Água e Terra: Vida e Cultura Guarani: Ações de recuperação e conservação ambiental e etnodesenvolvimento em aldeias indígenas Guarani do RS, o qual está sendo realizado pelo Instituto de Estudos Culturais e Ambientais (IECAM) 5 desde 2011 , com o patrocínio da Petrobras, por meio do Programa Petrobras Socioambiental.

O trabalho está ocorrendo em nove aldeias indígenas guarani, localizadas nas regiões sul, centro e norte do Rio Grande do Sul. A área inclui os biomas Mata Atlântica e Pampa, abrangendo extensas áreas de mata nativa e dezenas de nascentes, com grande biodiversidade e

\footnotetext{
${ }^{5}$ O IECAM é uma organização da sociedade civil, sem fins lucrativos, fundada em 1991, direcionada para o estudo e o desenvolvimento de ações relacionadas com a sustentabilidade social e ambiental, que busca principalmente a revitalização de saberes tradicionais e da biodiversidade. Desde 2004, esta instituição tem criado um espaço de aproximação e de envolvimento com os Mbya Guarani, tendo desenvolvido diversos projetos relacionados com o etnodesenvolvimento e a etnoconservação, em uma perspectiva de construção e ação em conjunto com estes povos para o atendimento de suas demandas. www.iecam.org.br; www.iecam.org.br/projeto; www.iecam.org.br/facebook.
} 
presença de espécies endêmicas de flora e fauna; mas contando também com espaços em estados variáveis de degradação, principalmente devido ao cultivo de espécies exóticas (eucalipto e pinus), anterior à formação das aldeias. Cada aldeia apresenta características próprias, dependendo do histórico do processo de aldeamento e das especificidades da região, consistindo em áreas mais próximas ou mais afastadas do meio urbano, e mais degradadas ou mais preservadas. Portanto, em cada local foram desenvolvidas atuações diferenciadas, de acordo com suas características e com as ideias e demandas dos seus habitantes.

A atuação do IECAM por meio do projeto visa contribuir para a recomposição ambiental dessas aldeias e a melhoria da qualidade de vida das comunidades, a partir de atividades de coleta e intercâmbio de sementes, viveirismo, compostagem e reflorestamento com espécies vegetais nativas escolhidas pelos indígenas, as quais são utilizadas para alimentação, saúde (medicina tradicional), espiritualidade (rituais), e economia (confecção de artesanato para comercialização). Junto à revitalização de práticas tradicionais, o trabalho contempla o apoio à recuperação de áreas degradadas, melhoria da fertilidade do solo e produção de alimentos, incluindo o uso de técnicas agroecológicas, como adubação verde, adubação orgânica, agrofloresta e criação de hortas e canteiros de plantas medicinais, além do intercâmbio de sementes tradicionais, no sentido de contribuir para a segurança alimentar e para a autonomia.

Outro foco da atuação se refere ao desenvolvimento do etnoturismo nas aldeias, com objetivos de geração de renda para as famílias, valorização da cultura guarani e difusão da visão de mundo ecológica e dos saberes ambientais destes povos. O tema do etnoturismo se tornou um dos geradores da necessidade de se trabalhar com a questão dos resíduos nas comunidades, além de outros motivos que compõem o interesse, por parte de algumas lideranças, em mudar a forma como são descartados. Neste sentido, o trabalho inclui atividades direcionadas para $o$ destino adequado dos resíduos, com 0 aproveitamento do lixo orgânico para a compostagem, gerando adubo para as hortas e viveiros, e o condicionamento dos outros tipos de resíduos para a coleta. 
Como o projeto trabalha a partir da identificação das necessidades guarani, constitui uma contínua aprendizagem das suas formas tradicionais de resolverem questões, bem como do reconhecimento de momentos em que pode haver a contribuição de outras técnicas, algumas vezes necessárias devido às condições atuais das áreas. Diversas falas guarani durante o processo expressaram suas percepções sobre o modo como são recebidas essas técnicas, saberes e ideias provenientes da cultura ocidental, proporcionando reflexões sobre sua visão acerca da interculturalidade no âmbito deste tipo de atuação socioambiental. Além disso, o processo envolveu discussões entre indígenas e profissionais não indígenas de diversas áreas, como educação, agronomia, desenvolvimento rural, biologia e antropologia, proporcionando fontes de grande riqueza para reflexões sobre interculturalidade e interdisciplinaridade.

Um dos elementos para a reflexão se trata do próprio método utilizado para o desenvolvimento do projeto; portanto, o ponto de partida do artigo, após a apresentação do método da pesquisa, é a descrição e discussão das estratégias utilizadas, em diálogo com pesquisadores (as) de outras ações socioambientais.

Partindo desses procedimentos, em um segundo momento, o texto desenvolve reflexões sobre alguns pontos críticos que foram identificados, os quais implicam no diálogo entre culturas no uso de técnicas como viveirismo, reflorestamento, agroecologia, etnoturismo e destinação de resíduos sólidos. As narrativas mostram um pouco da história da trajetória intercultural de diálogo sobre estas práticas, trazendo uma amostra de como conexões entre culturas vão emergindo ao longo das ações e das suas construções. Além de contribuir para reflexões sobre modos de lidar com as intervenções e seus possíveis impactos positivos ou negativos, servem como exemplos de construção intercultural, conduzindo até uma discussão mais geral.

Essa discussão mais ampla se consolida na terceira parte do trabalho, contemplando opiniões guarani sobre interculturalidade, as quais se manifestaram naturalmente, tanto durante a relação cotidiana com os técnicos, como nas atividades de avaliação do projeto e nos encontros sobre temas diversos, em que havia trocas entre conhecimentos das diferentes culturas. Estas percepções indígenas são 
trazidas em diálogo com outros autores, desenvolvendo uma discussão sobre o tema, e proporcionando o delineamento de novas questões para reflexão.

\section{Método}

O método de trabalho do Instituto de Estudos Culturais e Ambientais abrange a integração entre a pesquisa e a atuação indigenista, como forma de avaliação e de contribuição para a construção teórica e prática das atuações socioambientais com povos indígenas. No caso deste artigo, reúne dados específicos referentes ao tema da interculturalidade, obtidos durante o desenvolvimento de dissertação de mestrado6, complementados e atualizados com entrevistas e visitas posteriores.

A composição metodológica da investigação abrange observação participante, etnografia e entrevistas semiestruturadas. A observação participante é uma das estratégias que fazem parte do trabalho do IECAM, e também se constituiu como importante instrumento da pesquisa. Apresenta grande relevância na contínua construção do processo, permitindo um aumento gradativo da aproximação com os Guarani, buscando a aprendizagem e a compreensão de seus hábitos e opiniões. Esta é desenvolvida durante todo o tempo de convívio, nas conversas ao redor do fogo, na partilha de alimentos, nas visitas às casas, nos encontros e oficinas e nos trabalhos diários, percorrendo as trilhas das aldeias, atuando coletivamente nos viveiros, nas roças e no plantio de mudas. Nestas ocasiões, surgem naturalmente conversas sobre as plantas, a paisagem, os resíduos, a cultura, a saúde. Por meio destes diálogos informais e do convívio cotidiano, são trocados exemplos, ideias e mensagens, provenientes de ambas as culturas, contribuindo para a observação e registro de percepções sobre interculturalidade. Além do acompanhamento de atividades nas aldeias, a observação abrangeu a participação nas reuniões da equipe, bem

\footnotetext{
${ }^{6}$ Parte dos dados e reflexões foi obtida a partir da dissertação de mestrado Educação ambiental indígena e interculturalidade: reflexões a partir de percepções Mbya Guarani, desenvolvida no Programa de PósGraduação em Educação (PPGEDU) da Universidade Federal do Rio Grande do Sul, e com a participação no grupo de pesquisa "Educação Ameríndia e Interculturalidade".
} 
como conversas informais realizadas durante as viagens.

A observação participante foi acompanhada pelo olhar e escrita etnográficos, com registro em diário de campo, incluindo descrição detalhada e contextualizada das situações, com falas indígenas e não indígenas. A escolha da etnografia se dá devido à caraterística deste método, de acordo com Engers (1994), de abordagem dos fenômenos e comportamentos humanos tendo como referência o seu contexto social, buscando a compreensão do ponto de vista do público com o qual estamos trabalhando, com seus próprios significados, proporcionando identificar relações entre determinados comportamentos culturais e a especificidade da sua visão de mundo.

Foi trazido ao trabalho o exercício do olhar e do ouvir descritos por Rocha e Tosta (2009): ver as coisas como elas se apresentam aos olhos, sem julgar ou desejar que fossem diferentes, buscando a compreensão daquilo que se apresenta e ouvindo diferentes pontos de vista, com uma escuta de abertura e acolhimento, não discriminadora. Como a circunstância que proporcionou o convívio e a observação na aldeia foi a participação dos (as) pesquisadores (as) na função de técnicos (as) do IECAM, houve o cuidado de uma reflexão sobre o envolvimento, em direção a um envolvimento reflexivo, com sentido, observando como as perspectivas vão mudando, através dos encontros e desencontros, entusiasmos e frustrações, identificações e estranhamentos. São exploradas as transformações mútuas originadas através da atuação e as questões geradas a partir deste processo.

Em um segundo momento, visitas foram realizadas a quatro aldeias participantes do projeto, para conversas com os caciques, seus familiares, professores e outras pessoas que estavam presentes. Nestes encontros ocorreram diálogos informais, com a apresentação das reflexões desenvolvidas a partir das vivências anteriores e a escuta de suas opiniões e contribuições sobre as ideias apresentadas. Mais recentemente foram desenvolvidas entrevistas semiestruturadas com a coordenadora do projeto, o cacique da Aldeia da Lomba do Pinheiro e a diretora da Escola Estadual Indígena de Ensino Fundamental Anhetenguá, proporcionando a atualização das reflexões.

A metodologia envolveu, ainda, a pesquisa de materiais do IECAM: relatórios, relatos de atividades, filmes, materiais de divulgação e textos 
produzidos pela equipe técnica durante o desenvolvimento da atuação. No caso deste artigo, as observações, escutas, leituras e interpretações tiveram como foco o estudo do método utilizado pelo instituto, as relações indígenas e não indígenas durante o processo, as formas de planejamento e execução do projeto, e as mudanças práticas e teóricas ocorridas ao longo da atuação.

\section{A interculturalidade nos procedimentos e estratégias do projeto}

Em uma relação de parceria, o projeto foi construído junto com os caciques e lideranças das nove aldeias participantes, especialmente com Cirilo Morinico, cacique da Teko'a Anhetengua (Aldeia da Lomba do Pinheiro). A metodologia utilizada no trabalho do IECAM parte da escuta das demandas guarani e da busca conjunta de soluções, de modo que a atuação se fundamenta no respeito e na valorização de sua cultura, mas leva sugestões de formas ecológicas de resolver os problemas derivados das condições atuais de vida, propiciando, quando necessário, outros tipos de saberes e estruturas físicas necessárias para lidar com algumas questões. Desse modo, o desafio da dialogicidade intercultural é constante, em um cotidiano de trabalho em que se lida com a especificidade de sua visão de mundo, seu ritmo de vida e seu jeito de ser, mas se leva outros conhecimentos, opiniões e meios para execução, incluindo recursos financeiros, através do financiamento do Programa Petrobras Socioambiental, como o pagamento de monitores indígenas (cuidadores), materiais, infraestrutura, viagens e alimentações para a realização das atividades.

O processo educativo é construído coletivamente, por meio de conversas informais e reuniões. Estas ocasiões são aproveitadas para estimular a troca de ideias sobre ações para a resolução de questões ambientais da aldeia. Através destes diálogos e reflexões são organizados elementos estruturais para a melhoria da situação ambiental do local e são construídas atividades educativas, como oficinas e encontros sobre temas diversos, direcionados para adultos, jovens e crianças, envolvendo reflexão e ação, e contemplando dinâmicas peculiares para cada faixa etária. Em cada aldeia há um ou 
dois monitores que atuam mais diretamente no projeto, além dos caciques, agentes de saúde, agentes de saneamento e professores.

A interculturalidade se manifesta na própria escolha metodológica, pois além da observação participante, alguns métodos utilizados no trabalho fazem parte da cultura guarani e foram sugeridos por eles, como os grupos de trabalho e os potirõ (mutirões). Com a formação de grupos de trabalho, cada grupo fica responsável por alguma atividade comum a todos, como coleta de sementes e frutos, plantio de espécies arbóreas, medicina tradicional, produção agrícola, etc. Os mutirões reúnem esforços de muitas pessoas em torno de uma mesma atividade, sendo importantes não só para as ações práticas coletivas, mas para a convivência e integração. São realizados mutirões para plantio de adubação verde, manutenção do pomar, plantio de mudas e coleta de resíduos, por exemplo.

A atuação também contempla atividades específicas para as crianças, envolvendo a realização de conversas, práticas, desenhos, brincadeiras e lanches coletivos. Além destes momentos peculiares, as crianças costumam participar de todas as ações, estando bastante envolvidas nas dinâmicas do projeto, como os encontros e oficinas, as atividades de viveirismo, plantio, manejo da composteira e limpeza das áreas.

Nas aldeias que possuem escolas, estas são envolvidas no andamento do projeto, de acordo com suas possibilidades. A relação da escola com a comunidade tem sido muito importante na atuação, em ações educativas relacionadas com destino de resíduos, viveirismo, reflorestamento e cultivo de alimentos. Além de somar forças às ações comunitárias, essa relação contribui para o fortalecimento da educação escolar indígena diferenciada, estimulando aprendizagens a partir de ações práticas relacionadas com a cultura e com as questões indígenas. Resultados positivos estão sendo obtidos com este tipo de integração, como, por exemplo, em algumas escolas indígenas do Alto Rio Negro, conforme Silva e Cabalzar (2012, p. 400), as quais se envolvem intensamente no enfrentamento das questões comunitárias, incluindo o manejo ambiental. Lima e Sato (2011, p. 12) descrevem relação semelhante, no que diz respeito ao planejamento de aulas dentro de contextos ambientais, a partir de atividades práticas desenvolvidas em 
viveiro de mudas, meliponário e quintais, inseridas como conteúdo curricular da escola.

Outras estratégias metodológicas utilizadas pelo IECAM constituem principalmente planejamento com o uso de mapas, reuniões, encontros, oficinas, entrevistas e registro audiovisual. Os encontros se apresentam como um instrumento intercultural importantíssimo para planejamento, execução e avaliação das ações/atividades do projeto, além de contribuir na abordagem de temas específicos, construídos a partir da expressão de demandas que ocorre espontaneamente ao longo da atuação. A própria preparação, realização e avaliação dos encontros mostra a característica da interculturalidade, envolvendo uma série de reuniões, conversas informais e visitas que incluem um conjunto de combinações e negociações, manifestando elementos convergentes e divergentes entre ambas as culturas.

De modo semelhante, Silva (2007, p. 104), com relação ao trabalho com o povo Kanamari no médio Juruá, se refere a diversas atividades anteriores preparatórias para a realização de encontros, incluindo viagens das equipes para todas as aldeias, com reuniões e conversas informais, resultando na formulação das questões e construção da pauta dos eventos. Silva (2007, p. 94) relata que as comunidades determinam a realização de cursos e assumem os eventos no que se refere à administração, escolha dos conteúdos, metodologia e didáticas.

No caso do IECAM, a construção das atividades, desde o planejamento até a execução, é um trabalho conjunto, no sentido de uma crescente autonomia indígena, de modo a prever diferentes graus de participação indígena e não indígena, proporcionando a manifestação da interculturalidade de diversas formas. Alguns encontros e oficinas são construídos para possibilitar que a maior parte do tempo seja vivenciada somente entre os Guarani, proporcionando a troca de experiências, ideias, sementes e mudas entre as aldeias, além da reconstituição/revitalização de saberes e de hábitos relacionados com o uso e o manejo sustentável dos sistemas naturais, muitas vezes ainda desconhecidos pelos jovens. A confecção artesanal da erva mate, a produção de alimentos típicos indígenas e a construção de habitações tradicionais, como a opy (casa de reza) são exemplos desta 
revitalização.

Outros encontros contam com a participação dos (as) técnicos (as) durante todo o tempo, mas são conduzidos inteiramente pelos Guarani. O modo como alguns caciques coordenam este tipo de encontro valoriza a interculturalidade, mantendo o seu modo de condução das atividades, mas estimulando a participação dos não indígenas. Eles falam algumas vezes em guarani e algumas em português, possibilitando um resguardo, através da língua, daquilo que deve ser conversado somente entre eles. Quando falam em português, muitas vezes demonstram valorização e gratidão pelo trabalho desenvolvido, mas também questionam o que não concordam e expressam suas demandas. A condução costuma envolver os (as) participantes em um clima que contempla a arte, o sentimento e a espiritualidade. Em alguns casos a atividade termina com música, através do coral da aldeia, e com a despedida no modo guarani, em que todos ficam em uma fila, inclusive os (as) técnicos (as), e um de cada vez vai passando e se despedindo.

Encontros de avaliação e de planejamento são organizados com um formato em que a presença da equipe ocorre apenas nos momentos da abertura e do fechamento, para a escuta das avaliações, demandas, propostas e encaminhamentos. Há ainda outro formato de encontros e oficinas, o qual é conduzido pelos (as) profissionais do projeto, com tradução na língua guarani, onde são discutidos temas específicos e possibilidades de soluções, de acordo com as demandas apresentadas. Estas atividades buscam estimular a participação de todos, podendo abranger o uso de imagens, o planejamento das áreas com o uso de mapas, ou a experiência prática de alguma técnica ecológica, como a compostagem, a adubação verde e a elaboração de biofertilizantes e defensivos naturais. Foi observada a importância de que mesmo os encontros conduzidos por não indígenas proporcionem práticas significativas para os Guarani, como momentos de música, partilha de alimento, mapas e desenhos, atividades ao ar livre e práticas.

Além do planejamento e execução dessas atividades, a interculturalidade se manifestou nos planos de manejo das áreas, com a elaboração de mapas, cujo processo de construção gerou momentos muito ricos em termos de trocas de informações e ideias. Alguns 
representantes guarani de cada aldeia participaram ativamente da elaboração, conduzindo os (as) técnicos (as) nas áreas para a realização do georeferenciamento, mostrando os limites territoriais e a localização de elementos importantes, trazendo informações e participando nas decisões. Com estes dados foram construídos os mapas de "uso da terra" referentes a cada aldeia, os quais foram utilizados em diversos momentos para planejamentos conjuntos das áreas de plantio, se constituindo como instrumentos com potencialidade de gerar autonomia, podendo ser apropriados pelos indígenas e utilizados mesmo em períodos de intervalo entre projetos.

A questão da autonomia é bastante valorizada entre os Guarani, se encontrando presente em alguns dizeres relacionados com a continuidade do projeto, os quais retratam uma vontade de que o processo continue, mas de um modo em que consigam obter uma contínua emancipação e suficiência. Ao mesmo tempo em que valorizam o trabalho como uma boa oportunidade, e que precisa ter seguimento, também percebem a importância do cuidado para não desenvolver uma dependência dos não indígenas para a realização das atividades, conforme a fala de Felipe Brizoela, da Teko'a Pindoty, do município de Riozinho: "O projeto precisa continuar mais um tempo, mas não é pra vida toda. Nós precisamos nos fortalecer para continuar por nossa conta, sem precisar de projetos". De modo semelhante, a declaração seguinte reflete este interesse por uma sequência e constância do trabalho socioambiental, junto com sua contribuição para a autonomia:

Antes a gente vivia com a mata, hoje com pouca área,
dependemos dos projetos. A estufa é importante, mas
quando termina o projeto não conseguimos continuar,
porque precisamos de atividade que dá renda, como o
artesanato. E pra estufa gerar renda alguém tem que
estar presente, pra ajudar a organizar, negociar. O
projeto não pode ser temporário, tem que ter recurso
pra continuar. A gente quer caminhar sozinho, não
depender do branco, mas ainda não está preparando
pra andar só (Entrevista com Cirilo Morinico, cacique da
Tekoa Anhetenguá, 2016).

Com relação à abordagem da interculturalidade para o alcance da autonomia, Silva (2007, p. 90) destaca a importância do estabelecimento 
de objetivos de longo prazo neste tipo de atuação, pois implica mudanças comportamentais e de perspectivas. Silva (2007, p. 116) descreve como características importantes do trabalho o fortalecimento das organizações e do sistema pedagógico tradicional, a criação de espaços de reflexão e formação e o apoio ao protagonismo indígena. Para Silva (2007, p. 94), o diferencial deste tipo de experiência indigenista alternativa se refere à viabilidade de valorizar a expressão indígena produzida no universo das aldeias, com suas especificidades, proporcionando um diálogo em que ambas as partes possam se exprimir de modo independente, de acordo com sua realidade, visão de mundo, ideias e saberes.

Para que isto seja possível, é necessário um tempo suficiente de convivência, em que as relações possam ser construídas e alimentadas. No caso do IECAM, além do método escolhido (dialógico, participativo e prático), o sentimento que impulsiona as ações na sua trajetória com os Guarani proporcionou a aproximação e a edificação de vínculos importantes para este tipo de atuação, mas que necessitam de contínua nutrição, conforme a opinião da diretora da escola da Aldeia da Lomba do Pinheiro.

O IECAM já tem trajetória com os Guarani, eles já estão acostumados. O pessoal reconhece a atuação do IECAM, o trabalho das sementes, os encontros entre as comunidades. Mas é ao longo prazo, tem que ter tempo pra envolver mais a comunidade em todas as etapas, incluir mais conscientização, mais formação, capacitação na gestão dos projetos (Entrevista com Jacimara Heckler, diretora da Escola Estadual Indígena de Ensino Fundamental Anhetenguá, 2016).

É esta abertura de diálogo com os Guarani que permitiu o desdobramento de reflexões sobre o tema da interculturalidade no âmbito geral do trabalho e nas especificidades de elementos que foram discutidos ao longo do processo. Através dos diálogos entre indígenas e não indígenas em torno de técnicas e práticas que poderiam ser trabalhadas nas aldeias, de acordo com as demandas apresentadas e observadas, se delinearam alguns eixos de discussão, os quais são descritos a seguir. 


\section{Viveirismo, Reflorestamento e Agroecologia}

O viveirismo foi apresentado pelo IECAM para algumas aldeias, entre os anos 2004 e 2006, como uma forma de reintroduzir nas áreas indígenas espécies nativas importantes da tradição guarani, principalmente para confecção do artesanato e uso medicinal, as quais não estavam mais sendo encontradas nas aldeias e proximidades. Foram realizados, ao longo de alguns anos, reuniões e encontros para refletir e dialogar sobre esta atividade e, posteriormente, para seu planejamento.

A primeira iniciativa foi concretizada em Porto Alegre, em 2009, na Teko'a Anhetengua, após a definição da localização, construção e benção do viveiro-estufa, denominado pelos indígenas como poarendã ou yvyrendã (casa dos remédios ou das árvores). Foi necessário poucos meses para os Guarani apropriarem-se da estrutura e de muitas técnicas de viveirismo, talvez porque já tivessem o hábito da coleta de sementes e do cultivo de alimentos em roças familiares ou comunitárias, saberes que são transmitidos ao longo das gerações. Sr. José, cacique da Aldeia Campo Molhado, enfatiza esta forma de transmissão oral de conhecimentos milenares, abordando, por exemplo, a importância das sementes, que aprendeu a guardar com sua avó:

As sementes foram doadas aos índios por Nhanderu? Quando a gente se muda pra outro lugar, leva junto as sementes. Cada vez mais tem que cuidar para não perder, pois só as sementes dos índios vão continuar. Nhanderu também criou os pássaros para espalhar as sementes, mas hoje não tem mais muitos pássaros como Tucano e Jacu, por que o jurua ${ }^{8}$ quase acabou com eles (Entrevista com José Brizoella, cacique da Teko'a Nhuu porá, 2013).

O projeto arquitetônico do viveiro-estufa foi elaborado visando unir conceitos e necessidades apontadas pelos Guarani e padrões de construção que proporcionam maior durabilidade, menor manutenção e maior facilidade de manejo, incluindo um sistema de captação e

\footnotetext{
${ }^{7}$ Nhanderu significa "nosso pai”. Em português, nhande é nosso, e ru é pai.

${ }^{8}$ Denominação da língua guarani utilizada como referência às pessoas não indígenas.
} 
armazenamento da água da chuva para irrigação. Foram respeitados os costumes para a definição da localização e da orientação solar de acordo com seus conhecimentos espirituais, e foram utilizados alguns materiais tradicionais da construção de habitações e casas de reza, como a taquara e o capim-santa-fé. Foi incluído um espaço interno para realização de reuniões e oficinas, o qual também pode ser utilizado para atividades escolares.

O trabalho dos viveiristas guarani iniciou realmente no viveiro de Porto Alegre após um karaí (liderança espiritual) abençoar o local. No primeiro ano, três monitores ou cuidadores indígenas se dedicaram e se apropriaram desse viveiro. Atualmente, os conhecimentos e práticas do viveirismo são repassados pelos próprios cuidadores guarani, além de técnicos (as) não indígenas.

Como as outras atividades do projeto, o viveirismo procura respeitar o dom, o desejo e a aptidão de cada indígena para se entregar à prática. Assim como alguns guarani dedicam-se à semeadura e cultivo no viveiro, outros preferem se ocupar com o plantio, rega e cuidados das mudas e árvores. O termo "cuidadores" para designar viveiristas e jardineiros se originou de expressões guarani relacionando os termos plantas e crianças, filhas, especialmente da fala do primeiro viveirista do projeto:

As plantas têm que ser cuidadas como crianças, alimentadas, regadas, até crescerem, para irem para a terra, para dar frutos, e para as sementes, com a vontade e benção de Nhanderu, serem levadas pelo vento e virarem novas plantas (Entrevista com Feliciano Duarte, Teko'a Anhetengua, 2014).

A Teko'a Ka'aguy pau, em Palmares do Sul, uma aldeia que não costuma ser atraída por intervenções não indígenas, se interessou pela construção de um viveiro-estufa, com o mesmo projeto arquitetônico e padrões de construção do viveiro de Porto Alegre, a qual se efetivou em 2015. O cuidador guarani Feliciano, da aldeia de Porto Alegre, vem repassando e trocando saberes e práticas com o Sr. Agostinho e seu filho, cacique Eduardo, viveiristas da aldeia de Palmares do Sul. Outras aldeias do Sul do Brasil também estão querendo um viveiro, sendo a produção e comercialização de mudas avaliada e apontada pelos 
Guarani como uma futura fonte de renda para as aldeias.

Apesar do reconhecimento de que o viveirismo não é uma atividade originária de sua tradição, não é visto pelos Guarani como uma interferência cultural negativa, por se tratar de uma demanda atual de muitas áreas:

Se nas aldeias guarani tivesse espaço e árvores, não precisaria dos viveiros, mas tem aldeias que não têm mata e que não têm nenhuma árvore. Há uma interferência, mas de modo positivo, para o cultivo de plantas que são da nossa religião e medicina (Entrevista com Eloir de Oliveira, cacique da Teko'a Nhundy, 2013).

Após o período de coleta, aquisição, distribuição e troca de sementes e mudas, foi iniciado o plantio para a recuperação de áreas anteriormente degradadas, principalmente por monoculturas de eucaliptos. Na aldeia de Granja Vargas, em Palmares do Sul, e na aldeia de Torres, por exemplo, espécies de frutíferas e palmeiras nativas foram substituindo os eucaliptos, retirados com o acompanhamento da Fundação Nacional do Índio (Funai), cuja madeira está podendo ser comercializada ou utilizada em construções de casas e como lenha.

O plantio de espécies nativas para a recuperação das áreas foi realizado pelos próprios Guarani, por técnicos da equipe (agrônomos e biólogos) e por jardineiros, esses últimos quando se tratava de espaços maiores, como na aldeia de Torres, onde a área trabalhada alcançou mais de 30 hectares.

Respeitando as especificidades de cada aldeia, o tempo e a distribuição das atividades de acordo com o gênero e dom de cada indígena, cada teko'a escolheu um ou dois monitores e plantadores indígenas e o engajamento propiciou o intercâmbio de sementes e mudas entre as aldeias, o cultivo, o plantio e o manejo de mais de noventa espécies nativas da flora da Região Sul do Brasil, escolhidas pelos Guarani, importantes para sua alimentação, medicina tradicional, confecção do artesanato e de instrumentos musicais, e uso em rituais e cerimônias.

O cultivo e o plantio priorizaram, inicialmente, a segurança alimentar, através da ampliação das áreas de roçados tradicionais onde 
são cultivados, em sistema de consórcio e com períodos de pousio, frutíferas nativas e alimentos como milho, feijão, mandioca, abóbora, amendoim, banana e melancia. Como algumas áreas estavam bastante degradadas e com o solo fraco ${ }^{9}$, foram realizadas oficinas e mutirões, com o uso de técnicas da agrofloresta e agroecologia, incluindo práticas de enriquecimento do solo, como adubação orgânica (compostagem e bioferilizantes) e adubação verde, além de defensivos naturais e consorciação de cultivos. Foram escolhidas espécies normalmente cultivadas pelos Guarani, junto com tipos de adubação verde também utilizadas por eles, como o feijão-miúdo, usado como alimento, e a crotalária, cujas sementes são aproveitadas para confecção de artesanatos.

Espécies arbóreas nativas de importância para cada aldeia foram inseridas nos sistemas agroflorestais e para a recuperação e conservação dos ambientes naturais e cursos d'água, especialmente frutíferas, araucária, palmeiras nativas do Sul do Brasil e erva-mate. No início do trabalho com as aldeias, foi identificado que a erva-mate (///ex paraguariensis), quando presente nas áreas indígenas, existia em pequeno número, com exceção da Aldeia Campo Molhado, que já possuía grandes áreas de mata nativa, com araucária (pinheirobrasileiro) e erva-mate. Esta espécie é utilizada no chimarrão, cuja tradição é de grande importância no Rio Grande do Sul, tendo sido herdada dos Guarani. Expressões do cacique José, da Aldeia Campo Molhado ilustram esta questão:

Conheci a erva-mate com minha avó. Naquele tempo ela não comprava na venda. Eu subia pra pegar o galho, tirava e ela sapecava no fogo. Pendurava em cima do fogo e tirava em um pedaço de pano a parte que ia secando, depois pilava. Tinha erva-mate no mato, na beira da estrada. Hoje a gente compra na venda. A gente tomava o mate de taquarinha. Minha avó só fazia de taquara e a cuia de porongo, plantada. Nhanderu também tomava assim (Entrevista com José

\footnotetext{
9 Os Guarani ocupavam anteriormente estes territórios, mas foram expulsos através dos processos de colonização. Atualmente retomam estas terras e constituem suas aldeias, por meio de intensos trabalhos de luta para demarcação e regularização. No entanto, muitas destas áreas se encontram em estados avançados de degradação, devido à acelerada exploração econômica. Na aldeia da Lomba do Pinheiro, por exemplo, o local é bastante degradado, com a presença de muitas árvores exóticas, como pinus e eucalipto, sendo os solos arenosos e pobres em matéria orgânica, desgastados pela excessiva exploração destas monoculturas.
} 
Brizoella, cacique da Teko'a Nhuu porá, 2013).

Para os Guarani, a erva-mate, presente de Nhanderu, é denominada caá (erva saborosa), sendo o chimarrão chamado de caá-i (água de erva saborosa), considerado uma bebida de grandes virtudes, que renova as forças, mitiga o cansaço, alimenta o corpo e cura a alma, mantendo o coração alerta e alegre. Este conhecimento é um exemplo da relação entre corpo e alma, que mostra uma visão de integração entre ambiente, cultura, sentimento e espiritualidade, a qual é característica na forma mbya guarani de viver e de compreender a realidade.

Essa perspectiva integradora também contribui para uma ampla e detalhada visão espacial e capacidade de percepção das conexões entre diversos elementos, possibilitando que a construção e a interpretação de mapas se constituam como excelentes ferramentas de diagnóstico e de planejamento. Aproveitando esta aptidão, foram construídos, ao longo de quatro anos, mapas de "uso da terra" com cada aldeia participante do projeto, visando um conhecimento mais detalhado do manejo das áreas e a contribuição no planejamento e acompanhamento da gestão sustentável dos territórios e do processo de reconversão produtiva, recuperação e conservação ambiental. Os mapas estão auxiliando também na realização de rotas e atividades de etnoturismo, fonte de renda para as aldeias. Foram definidas conjuntamente sete classes ou categorias de "uso da terra": Reconversão produtiva (kokue), Recuperação de áreas degradadas (yvira'iky ty), Conservação de biomas (ka'aguy), Corpos d'água ( $y y)$, Áreas de passeio e trilhas (tape'i), Áreas construídas (oo renda) e Áreas de lazer e esporte (ougaty).

Estes mapas podem contribuir nos processos de construção dos Planos de Gestão Territorial e Ambiental (PGTA), importante instrumento de implementação da Política Nacional de Gestão Territorial e Ambiental de Terras Indígenas - PNGATI (Decreto 7.747, de 5 de junho de 2012), os quais devem expressar as especificidades ambientais, culturais, econômicas e políticas de cada povo indígena, através de procedimentos que garantam sua autonomia, autodeterminação e protagonismo, de modo a assegurar a integridade do patrimônio indígena (FUNAI, 2013, p. 8). 
Gomide e Santos (2015), através do acompanhamento de levantamentos de fauna e vegetação em áreas indígenas, também chamam a atenção para a profundidade dos seus saberes quanto à identificação das espécies e relação com o ambiente e a cultura, incluindo suas representações cosmológicas. O trabalho com mapas mentais mostrou que a construção vai além de uma representação cartográfica, refletindo a expressão de toda uma riqueza de saberes, experiências vividas, lugares, trajetos e ambientes, em um processo de elaboração participativa de conhecimento. Os autores salientam o quanto é fundamental que sejam feitas propostas pelos próprios indígenas sobre o uso e manejo dos recursos naturais de seus territórios, e como levantamentos deste tipo podem contribuir para a discussão e a estruturação dos planos de gestão das terras indígenas, colaborando com alternativas sustentáveis para estes povos.

\section{Etnoturismo}

O interesse no etnoturismo por parte de representantes de algumas aldeias foi observado inicialmente a partir da preferência pela comercialização do artesanato no próprio local, de modo a evitar a necessidade de deslocamento para as cidades, como mostra a fala de José Rodrigues, cacique da Aldeia Campo Molhado: "Não queremos sair da aldeia para vender nosso artesanato. Queremos receber o comprador aqui, por isso queremos o turismo".

Nas conversas com alguns guarani, também foi identificada uma vontade de receber pessoas em suas aldeias para mostrar seu modo de ser, provocar outros tipos de vivências:

O turismo nas aldeias ajuda a fortalecer a luta do povo Guarani, divulgar a cultura, para as pessoas vivenciarem um pouco da vida da aldeia e conhecerem a nossa realidade, ver a situação precária em que vivemos. Se não olharem não ficam sabendo, não respeitam (Entrevista com Eloir de Oliveira, cacique da Teko'a Nhundy, 2013).

Além de mais uma forma de geração de renda, o etnoturismo, 
juntamente com outras iniciativas consorciadas, surge como uma alternativa de visibilidade à causa e realidade indígenas. Herculano (2007) salienta a relevância do estímulo à participação indígena na sociedade, de modo a proporcionar mudanças na representação de índio no Brasil, na qual ainda prevalece o preconceito e a intolerância cultural. Este distanciamento foi citado por alguns guarani, como o cacique Miguel, da aldeia de Riozinho: "Muitas vezes as pessoas falam dos índios sem saber sobre qual etnia estão se referindo, mas cada etnia tem sua forma de ser e de fazer as coisas". O cacique Eloir, da Aldeia da Estiva, também menciona a visão que as pessoas possuem dos indígenas: "Se baseia muito nos livros, com a referência sobre os índios do passado, mas o Guarani já mudou muito, sem deixar de ser Guarani”.

O etnoturismo pode ajudar na implementação da lei 11.645/200810, e enriquecer o ensino de vários conteúdos escolares. Também pode ser um elemento de grande potencial para a Educação Ambiental, em uma abordagem que integra a valorização da diversidade cultural e ambiental. Os Guarani trazem lições de vida essenciais, que proporcionam à sociedade uma visão de mundo mais ecológica, com valores como cooperação, reciprocidade e simplicidade. Ao longo do projeto foi observado o potencial educativo mbya guarani, com a sua forma oral, vivencial e criativa de transmissão de saberes, em grande riqueza de representações simbólicas, visuais e cartográficas, manifestações artísticas e culturais, as quais podem ser cultivadas, como forma de valorização cultural.

Nesse contexto se revela a potencialidade do etnoturismo em áreas indígenas, como forma de geração de renda, facilitação da comercialização do artesanato, contribuição na revitalização cultural e valorização de suas tradições, podendo contribuir para a redução do preconceito e sensibilização para valores e atitudes mais ecológicos. No entanto, como outros meios de geração de renda para aldeias indígenas, precisa envolver toda a comunidade na execução, gestão e aproveitamento dos recursos obtidos. A atividade deve ser construída de modo participativo e intercultural, de acordo com a realidade ambiental e cultural de cada área indígena, conforme as demandas e

\footnotetext{
${ }^{10}$ Lei federal que inclui no currículo oficial da rede de ensino a obrigatoriedade da temática "História e Cultura Afro-Brasileira e Indígena".
} 
interesses das comunidades, e com respeito aos seus tempos e ritmos:

Os Guarani têm que saber o que querem mostrar e as visitações não podem ser todos os dias, pois a aldeia precisa ter o tempo pra si. Tem que ser de forma planejada, uma ou duas vezes por semana, pois se ocorrer todos os dias vai mudar o tempo da aldeia (Entrevista com Eloir de Oliveira, cacique da Teko'a Nhundy, 2013).

Nesta perspectiva, o IECAM trabalhou cerca de dois anos com sensibilização à temática do etnoturismo nas aldeias, através de conversas e reuniões, bem como na convivência com as comunidades, sempre numa postura de respeito e amizade. O processo permitiu 0 estabelecimento de pontos a serem conhecidos por visitantes, salvaguardando as especificidades de cada aldeia. Foram elaboradas coletivamente rotas turísticas e trilhas ecológicas, com o preparo da infraestrutura necessária para esta finalidade, e a definição de algumas orientações.

Em uma aldeia mbya guarani os visitantes podem conhecer a casa de reza da aldeia, a opy, mas não entrar em seu interior, pois é vedado aos juruá. Apresentações musicais são realizadas na frente da opy. A alimentação tradicional é um bom atrativo, com pratos típicos, principalmente à base de milho, amendoim, farinha de trigo, mandioca, mel e frutas. O artesanato mbya guarani é apresentado, com seus simbolismos e significados, podendo ser comercializado. Estas obras são representações cosmológicas de suas vidas, crenças e mitos, sendo altamente representativas da cultura guarani, principalmente as esculturas zoomorfas, assim como os colares, cestarias e outros. A cosmologia guarani é muito vasta, contemplando, por exemplo, mitos acerca de suas origens, como o mito do cedro, do quati e do sol. $\mathrm{O}$ visitante pode ouvir a história do mito da criação do sol através do cedro, árvore sagrada, e mesmo plantar uma muda na aldeia.

A Teko'a Pindoty é um antigo sítio de 24 ha, área adquirida pela Funai, onde vive uma família mbya guarani que cultiva árvores frutíferas, roças e hortas e cria porcos e galinhas. Esta família está implantando seu teko'a e é uma das aldeias interessadas na rota do etnoturismo, com o entusiasmo do sr. Alberto, que considera importante que sua 
aldeia tenha todas as características e costumes de uma aldeia guarani. Com o apoio do trabalho do IECAM, foi construída uma opy, com as paredes de madeira e taquara, amarradas com cipó e preenchidas com barro, e o telhado de folhas de pindó (palmeira-gerivá).

Na Teko’a Nhuu porá, Aldeia Campo Molhado (Riozinho, Maquiné, Barra do Ouro e Caraá), seus moradores valorizam a oportunidade de receber visitantes, vender artesanato, mostrar e falar de sua cultura, proporcionando a degustação da culinária tradicional guarani e o percurso de uma pequena trilha até um bosque de xaxins, onde há uma fonte de água pura, reverenciada pelo cacique José. Este cacique possui o dom da oratória e muita sabedoria, com conhecimentos ecológicos e mitos, além de belos desenhos que ilustram estes saberes. Através do projeto houve a participação no Fórum de Turismo do Vale do Paranhana, com reuniões na Faculdades Integradas de Taquara (FACCAT) e realização de oficinas com a comunidade. Atualmente a aldeia participa do rol de opções de visitação do circuito turístico do Vale do Paranhana, constando no respectivo folder de divulgação e site. As visitações têm ocorrido esporadicamente em parceria com uma hospedaria rural vizinha.

A Teko'a Nhundy (Aldeia da Estiva) recebe escolas e grupos eventualmente, mas algumas falas demonstram a necessidade de mais estruturas e apoio. Um representante desta comunidade falou da sua vontade de fazer um quiosque, uma construção de barro e taquara, "tipo uma mini opy, com fogo, comida típica, artesanato, para mostrar a cultura e para as pessoas poderem experimentar um pouquinho da vida guarani".

Na Teko'a Anhetenguá, Aldeia da Lomba do Pinheiro, os Guarani tiveram a iniciativa de elaborar uma trilha, e escolheram o igary (cedro) como a árvore principal a ser plantada ao longo do trajeto, além de planejar grande parte da visitação turística, tendo como início da visita a casa onde morava o cacique, que seria o "Centro de Memória Viva", onde poderiam ser expostas imagens, peças de artesanato, publicações, filmes e outros materiais. O trajeto passou a ser chamado de "Trilha do Igary" (Trilha do Cedro), ao longo do qual foram plantadas muitas mudas de cedro, além de ipê-amarelo, ipê-roxo e outras espécies. A trilha percorre toda a área da aldeia, passando por locais diversos, como 
matas, roças, opy, casas de barro, açude, viveiro e escola. Mas atualmente o pensamento do cacique mudou bastante:

A aldeia teria que se preparar muito mais pra receber os turistas, e talvez não seja o desejo de toda a comunidade. O sistema é mais de ficar fechado entre as famílias. Agora que estão abrindo pra algumas pessoas, mostrando a opy de longe. Teriam que discutir várias questões, como quem vai cuidar do lixo, do canto e da dança, como distribuir a renda. É um desgaste e um trabalho muito grande, teria que cobrar um valor alto do turista para valer a pena. Tem que valorizar a cultura, cuidar para o indígena não virar um produto (Entrevista com Cirilo Morinico, cacique da Teko'a Anhetenguá, 2016).

Ao mesmo tempo em que o etnoturismo apresenta potencialidade, mostra todo um trabalho contínuo em termos de apoio à estruturação, organização e gestão, e que precisa ser bem-planejado, realizado com muito cuidado, em proporções reduzidas e com estratégias diferenciadas para cada comunidade interessada, respeitando o seu tempo, ritmo e mesmo uma possível inconstância.

\section{Resíduos sólidos}

A questão da destinação dos resíduos sólidos apareceu inicialmente ligada às reflexões sobre o turismo, atividade que vem a corroborar com a necessidade de se manter limpas as aldeias, contando com o recolhimento do lixo através das prefeituras.

Apareceu ainda, durante o trabalho, um reconhecimento da saúde como relacionada com o manejo adequado de resíduos sólidos na aldeia, como em conversas com o cacique Cirilo, que também é agente de saúde da Aldeia da Lomba do Pinheiro, o qual se referia à importância de falar para as pessoas que o lixo jogado no chão pode atrair agentes causadores de doenças. A relação entre resíduos sólidos e doenças também foi trazida pelos alunos da escola, em atividade relacionada com a temática dos resíduos, quando foram apresentadas ilustrações sobre este tema e solicitado que falassem o que vinha na mente ao ver as imagens. 
O hábito de jogar resíduos no chão é comum entre os Guarani, desde quando eles não consumiam produtos industrializados e geravam somente resíduos orgânicos. Esta questão sobre como era o lixo antigamente e atualmente foi abordada na escola da Aldeia da Lomba do Pinheiro, através do professor Jerônimo, gerando reflexões interessantes sobre o consumo de produtos industrializados e as consequências desse modo de destinação das embalagens.

Algumas falas ao longo do trabalho, principalmente por parte de lideranças, foram revelando percepções sobre essa forma de descarte dos resíduos como um problema que consideram importante resolver. Esta noção pode ter influências de um processo intercultural, envolvendo indivíduos, grupos, instituições governamentais e não governamentais que já passaram pelas aldeias e já abordaram essa questão, mas também mostra relação com os valores guarani, transmitidos entre gerações, como o respeito pela natureza, fruto da sua percepção ambiental, sua cosmologia e seu modo de ser.

Sr. Miguel, cacique da aldeia de Riozinho, relata que seus avós já falavam sobre esse tema, sobre a importância de não deixar sujeira dentro de casa, de manter sempre bem limpo. De fato, nas visitas às aldeias é possível observar diversas vezes as mulheres varrendo os pátios das casas. Zanin (2009) relata este hábito da limpeza dos pátios que circundam as casas, com uma vassoura tradicional (typyxau), confeccionada com galhos de um arbusto, dizendo terem referido como motivo que "é para o sol nos abençoar, porque Nhamandu não gosta de pátio sujo".

Fica nítida, em diversas falas, a percepção dos diferentes tipos de lixo: "os que são da natureza" e "os que são criados pelos juruâ". O cacique Cirilo se refere a uma angústia proveniente dessa existência nas aldeias dos resíduos originados através de criações do juruá. Preocupação que também apareceu junto a outras questões, como o turismo, o consumo de produtos industrializados e a relação com a saúde.

A gente sabe que o lixo no chão é ruim, que não é da gente. A gente se preocupa, conversa sobre isso todo o dia, pensa no pátio que antigamente era limpo, pra não ter moscas, mosquitos, pra ter saúde. Todo mundo sabe disso, mas fica acostumado a jogar no chão. É 
difícil pra nós, mas vamos tocar nisso, vamos falar do lixo, vamos lutar pra mudar isso (Entrevista com Cirilo Morinico, cacique da Teko'a Anhetenguá, 2011).

Foi constatada ainda uma inquietação com relação ao lixo que os juruá trazem pra aldeia. Isto ficou claro quando o cacique Cirilo indicou os dizeres para as placas que eles queriam para a comunidade (Não jogue lixo no chão/Peity rive em eyty): "Tem que escrever em português e em guarani, porque a placa é pros brancos também, eles também jogam lixo aqui no chão da aldeia".

Outro elemento importante que surgiu na pesquisa foi uma percepção de mudança do ambiente com relação à presença ou ausência de resíduos no chão. A fala do cacique Cirilo, surgida espontaneamente em uma caminhada na aldeia após a realização de mutirão de limpeza, mostra a satisfação na percepção de que um ambiente sem lixo faz uma diferença, inclusive com relação a uma mudança no ambiente interno das pessoas, afetando a dimensão mental e emocional: "O lixo muda o que a gente vê. Quando tem lixo a gente só enxerga o lixo, mas quando a gente tira o lixo, enxerga o verde. Aí muda o que a pessoa pensa, o que ela sente. O verde inspira outros pensamentos".

Essa relação com os resíduos é bastante complexa e também pode estar ligada a um modo de se relacionar com as coisas em geral, que contempla o desapego e a visão cíclica de tudo, com seus ciclos de vida e morte. No entanto, foi observado que, apesar deste hábito de jogar no chão, eles se preocupam em juntar depois e dar outro destino, organizando mutirões para esta tarefa, colocando nas lixeiras, nas aldeias em que há coleta; solicitando sacos de lixo, latas e ajuda para conseguir a coleta de resíduos onde ainda não ocorre. Foi identificada uma valorização por parte dos Guarani das situações em que não indígenas se dedicam a tratar essa questão em suas aldeias, mas sempre dependendo da forma como são tratadas:

Tem que ter parceria pra conseguir resolver a questão do lixo, alguém de fora tem que estar presente. Só o cacique não funciona, se não tem aliado. Não é fácil falar do lixo sendo de dentro da aldeia. Tem que falar sempre, e tem que falar com muito carinho, com equilíbrio. Tem que ter lanche pra fazer atividade, tem que compartir (Entrevista com Cacique Cirilo, Teko'a 
Anhetenguá, 2016).

Pra nós é bom quando o não índio vem trazer sacolas e falar do lixo. Mas a gente não gosta quando as pessoas falam que as crianças estão de pés descalços. Isso não é sujeira, é que a criança já se acostumou com a terra, com a natureza (Entrevista com Cacique Miguel, aldeia de Riozinho, 2013).

O diálogo intercultural nesse e em outros temas parece exigir uma definição de limites entre uma imposição cultural de padrões de limpeza e higiene pessoal e a conversa aberta e respeitosa sobre aspectos que podem afetar diretamente questões de saúde e produzir impactos, como contaminação da água, produção de alimentos e doenças contagiosas.

\section{Percepções mbya guarani sobre interculturalidade em ações socioambientais}

Foram identificadas ao longo do trabalho manifestações sobre a importância de pessoas de outras culturas estarem se aproximando da causa indígena e se propondo a contribuir.

O desenvolvimento vai avançando, sem respeito, pisando nos pobres. Nós sozinhos não conseguimos muito, tem que vir gente de fora ajudar, tem que ter parceria. Hoje tem mais companheiros da causa, que respeitam a cultura guarani. Não podemos perder o vínculo com as pessoas aliadas e tem que ampliar esses aliados (Entrevista com Cirilo Morinico, cacique da Teko'a Anhetenguá, 2013).

Os dizeres acima proporcionam reflexões sobre a visão mbya guarani quanto à importância das parcerias, "companheiros" de diferentes culturas, se complementando, trocando ideias e experiências, construindo ações para atender às demandas das aldeias e da questão indígena como um todo, em uma visão transformadora.

No entanto, outras conversas mostram dificuldades inerentes a esta relação, no que tange a profundas diferenças de visão de mundo, e a importância de que a busca de conhecimento sobre aspectos da 
cosmologia indígena seja transformada em atuações práticas, de acordo com as demandas.

Não é fácil trabalhar na questão indígena. São dois mundos diferentes. Os índios têm que ser vistos como parceiros. Não adianta vir aqui na aldeia só pra perguntar sobre nossa cultura, nossa cosmologia, tem que trabalhar nossas necessidades, ver o que falta. Tem que caminhar junto, abraçar a causa indígena (Entrevista com Cirilo Morinico, cacique da Teko'a Anhetenguá, 2013).

É necessário o reconhecimento da complexidade desta relação, a qual não se trata de uma simples soma ou troca de saberes provenientes de diferentes culturas. Repetto $(2012$, p. 19) ressalta esta questão, lembrando que a discussão de temas com base na interculturalidade não deve partir apenas da ideia de diálogo entre culturas, mas acompanhar uma reflexão sobre os conflitos existentes nestas relações na sociedade.

É neste contexto complexo, não somente de grandes diferenças culturais, mas de conflitos históricos e ainda atuais, que a importância da relação de parceria entre representantes de diferentes culturas é pensada entre os Guarani, trazendo uma reflexão crítica sobre a história de colonização e dominação de uma cultura sobre outra, conforme a fala do cacique Cirilo: "Como fazer educação ambiental se não tem terra, não tem floresta? Como o branco que destruiu vem plantar e querer que a gente plante? $O$ índio não gosta que o branco venha dizer o que tem que fazer".

Estas percepções podem ser discutidas na perspectiva da interculturalidade crítica, no sentido atribuído por Walsh (2010), como processo contínuo de negociação, construído como projeto político, ético, social e epistêmico, que afirma a necessidade de transformação nas estruturas e relações de poder que alimentam a desigualdade, discriminação e dominação. Esta abordagem está relacionada com a Pedagogia Crítica, que iniciou com Paulo Freire nos anos 60, no sentido de projetos e movimentos que se desenvolvem em uma perspectiva de questionamento crítico, transformação e reconstrução. É uma interculturalidade com um sentido, direcionada para mudanças estruturais e nas relações, no que tange à justiça social, étnica e 
ambiental.

Oliveira e Candau (2010, p. 19) tratam da colonialidade epistemológica, a qual tem profundas raízes, em um processo histórico de destruição de subjetividades e de repressão de todo um arcabouço de conhecimento simbólico e imagético, com a reafirmação de uma superioridade cultural, gerando a colonialidade do saber e do ser. Os autores afirmam que um processo de reversão deste movimento, a decolonialidade, pressupõe a desconstrução e a reconstrução do saber e do ser, que precisa da visualização dos movimentos e das práticas sociais. Estas reflexões são bastante atuais, considerando-se que, ao contrário dessa visualização e devida valorização, hoje passamos por um processo de criminalização dos movimentos sociais.

A decolonialidade exige o reconhecimento de que ainda existe uma colonização do saber, e de que essa ruptura necessita de um exercício constante, individual e coletivo, de observação, superação e transformação. Neste sentido, Silva (2007, p. 90), com relação a processos educacionais desenvolvidos junto ao povo Kanamari, no médio rio Juruá, no Amazonas, se refere à necessidade de questionamento dos papéis das instituições e de seus representantes, para que ocorra uma real ruptura com o ciclo histórico de dependência e de autoritarismo existentes na região.

De modo semelhante, Gasché (2008, p. 386) aborda a importância da renúncia à reprodução de um sistema dominante, de forma a proporcionar um verdadeiro sistema educativo cooperativo. Essa renúncia passa pela adoção de uma postura crítica com relação aos mecanismos de dominação, junto ao questionamento das relações e posições de poder, que incluem instrumentos que reforçam a hierarquização de saberes, como, por exemplo, os cargos e diplomas. $\mathrm{Na}$ visão dos Guarani, o papel não é o mais importante, mas o interesse em acessar conhecimentos ocidentais varia conforme a aldeia e as pessoas, sendo que alguns querem ter acesso a capacitações e certificações:

Tem que ter mais cursos e capacitação, não só oficinas. Se não parece que a gente continua criança, pedindo. $\mathrm{Na}$ cidade tudo é dinheiro, tudo tem que pagar. A escola é muito importante, pra formar pessoas que fiquem trabalhando na aldeia. Meu sonho de ter Ensino 
Médio hoje aconteceu. Esperamos que os nossos jovens possam assumir responsabilidades, pra não depender de fora. Temos capacidade, só não temos escolaridade (Entrevista com Cirilo Morinico, cacique da Teko'a Anhetenguá, 2016).

Tendo em vista as diferenças entre aldeias, famílias e indivíduos, a visão guarani sobre interculturalidade em projetos socioambientais apresenta uma abrangência que contempla o espaço de valorização e expressão dos conhecimentos indígenas e o acesso aos saberes ocidentais, em uma concepção de simetria de conhecimentos. Com esta visão simétrica, Fehlauer (2010, p. 105), no contexto de realização de um curso de agroecologia em área indígena, critica os critérios hierárquicos da formação científica ocidental, que implicam na educação técnica como expressão etnocêntrica, com seus títulos e publicações, expressando a importância da desnaturalização destes critérios como condição para a possibilidade de uma proposta intercultural. O autor questiona as assimetrias relacionadas à imposição de uma suposta superioridade dos aspectos cognitivos sobre os práticos, destacando a importância do reconhecimento do valor das práticas indígenas, como uma forma de expressão criativa, um legítimo "saber-fazer".

Essa valorização do saber indígena passa pela abertura para a visualização da sua profundidade e riqueza, a partir de critérios e canais que não se resumem aos intelectuais, abrangendo, além do "saberfazer", elementos simbólicos, artísticos, intuitivos e míticos. A profundidade dos saberes guarani se manifestou nitidamente durante o trabalho em expressões como a do cacique Cirilo: "É um conhecimento milenar que a gente tem. Tem muita coisa no mundo indígena. É difícil falar tudo. Tem coisas que a gente nunca fala. É importante não falar".

Características de reciprocidade, complementaridade, sentimento, comunidade, simbolismo e arte se evidenciaram ao longo da pesquisa como muito frequentes e fortes na sabedoria mbya guarani, e constituem elementos cuja presença também é apresentada no trabalho de Kusch (2009), a partir de seu estudo com os indígenas quechua, com suas contribuições para a compreensão do pensamento indígena. Este autor traz uma profunda reflexão sobre o pensamento popular americano, colocando em evidência uma grande diferença entre o pensamento indígena e o ocidental, considerando-os respectivamente 
como pensamento seminal e causal. O seminal (indígena) é interno, vem do âmago, da origem, não precisa de muita explicação, pois se sente, se vive, no aqui e agora. O causal (ocidental) busca as causas externas e a delimitação dos problemas para seu enfrentamento com eficiência.

Essa descrição do pensamento indígena contempla intensamente a dimensão do sentimento. Kusch (2009) esclarece que no pensamento indígena há um predomínio do sentir sobre o ver, onde a realidade é sentida a nível afetivo antes de ser vista. Este registro da realidade através do sentimento traz a forte presença da afetividade, que para o pensamento ocidental tem um tom pejorativo. $O$ autor chama a atenção para a predominância de expressões relativas a decisões inteligentes que são traduzidas em termos que usam a palavra coração, como órgão que vê e sente, atuando como regulador intuitivo do juízo. Estas expressões também são bastante incisivas nas falas mbya guarani, como "pensar com o coração", "falar com o coração" e "agir com o coração".

Kusch (2009) destaca, ainda, a relevância do simbólico, que possibilita o acesso a saberes referentes a uma totalidade que não pode ser alcançada com um pensamento puramente racional, explicativo, fundamentado nas causas. Os símbolos, presentes nos mitos, nos sonhos, nas metáforas, conectam com arquétipos da dimensão espiritual e emocional, trazendo significados importantes, oferecendo o sentido profundo da cultura. A cultura indígena é ritualizada, estando relacionada com o sentimento de totalidade que se expressa nos rituais, através dos quais são afirmadas as raízes ancestrais e existenciais. A espiritualidade desempenha um papel importante nesta conexão, no predomínio do todo sobre a parte e do coletivo sobre o individual, e também se manifesta de forma estética, tendo a arte um papel fundamental.

A perspectiva de valorização simétrica dessas formas distintas de conhecimento traz ricas possibilidades de entrelaçamento e de complementaridade. Leff (2003 e 2009) se refere à potencialidade das bagagens culturais de diversos povos na contribuição para transformações e enriquecimentos culturais da sociedade, oferecendo elementos para a construção de uma nova racionalidade, integradora dos potenciais da natureza e da humanidade, das identidades culturais e 
dos valores humanos, em sistemas produtivos sustentáveis, elaborados e implantados por meio de processos dialógicos, de troca e conjugação de saberes.

Nessa concepção, Souza Santos (2005) expõe a importância de um pensamento de abertura, diálogo e articulação da ciência com outras formas de conhecimento, em construções que integram novas configurações de saberes. Estas construções se constituiriam em uma resposta a uma situação de crise epistemológica, implicando tanto em crítica ao relativismo que alimenta separações, como ao universalismo que impõe monoculturas do pensamento.

Mas o reconhecimento da relevância de uma conjugação desses diferentes saberes implica em uma dedicação para a construção de novas formas de relação, que possam realmente contribuir para aprendizagens conjuntas. Gasché (2008, p. 391) apresenta o termo "interaprendizagem" como uma noção-chave para todo o projeto educativo intercultural, que traduz a expressão de uma reciprocidade entre indígenas e não indígenas. O autor identifica a relevância da convivência dos atores de projetos educacionais interculturais com as comunidades onde ocorre a atuação, uma coexistência que fundamenta a aprendizagem conjunta entre indígenas e não indígenas.

A perspectiva da interaprendizagem proporciona não somente uma troca de saberes, mas a própria construção de um conhecimento mais rico e complexo. Noção semelhante foi constatada no discurso guarani ao longo da atuação, apesar de não utilizar o termo interaprendizagem. Tanto o modo de condução de atividades como alguns dizeres trazidos ao longo de todo o projeto refletem a importância que eles dão para um processo educativo que estimula as trocas de conhecimentos entre membros de diferentes aldeias e de diversas idades, e também a troca entre saberes de diferentes culturas. A valorização da aprendizagem ocorreu tanto com relação a técnicas não indígenas como entre os próprios indígenas, conforme os dizeres do cacique Miguel, da aldeia de Riozinho: "O projeto é um compromisso que temos em trabalhar e aprender juntos"; bem como a fala do cacique Eloir, da Aldeia da Estiva, no que se refere à participação dos mais velhos: "Através do projeto estamos aprendendo com o conhecimento dos técnicos, mas também com a gente mesmo, com os mais velhos e 
com o pessoal das outras aldeias".

Nessa aprendizagem intercultural, Silva e Nornberg (2009) destacam a importância de um diálogo entre culturas que permita que cada indivíduo seja aceito como legítimo na sua forma de ser, pressupondo a abertura para rever e transformar hábitos e convicções, construindo outros modos de ser, estar, viver, pensar, aprender e ensinar, em uma visão de diversidade e reciprocidade cultural, com contribuições mútuas e crescimento conjunto. Neste sentido, Silva (2007, p. 94) relata que na atuação com o povo Kanamari ambas as partes (indígenas e não indígenas) passaram por modificações, na medida em que se permitiram perceber e absorver a lógica das relações sociais, bem como a noção de tempo e seu uso.

É em uma abordagem de interaprendizagem que ocorrem, através do IECAM, atuações coletivas interculturais para a resolução de demandas, conforme a especificidade de cada aldeia, integrando conhecimentos tradicionais indígenas e saberes técnicos e científicos ecológicos, como o viveirismo, a agroecologia e o etnoturismo. Foi sempre muito presente nas reuniões entre os técnicos a preocupação com a forma de propor inovações, o cuidado para que sejam de acordo com as demandas, a observação das expectativas e do andamento das ações, e a flexibilidade para mudar as metas quando necessário.

Essa forma dialógica como foram trazidos conhecimentos e técnicas não indígenas foi valorizada por alguns guarani, como o cacique Eloir: "O trabalho da equipe é muito importante. O conhecimento técnico contribui muito para dar certo, mas se une ao nosso conhecimento, com respeito, sem imposição. Tudo é discutido, bem conversado". A opinião guarani sobre algumas técnicas e estratégias sugeridas pelos não indígenas ilustrou essa visão de se constituírem como conhecimentos que se somam à sua cultura, complementando, quando necessário, como salientou o cacique Miguel, da aldeia de Riozinho: "A gente não sabe tudo. Os técnicos nos ensinam muita coisa".

Através das escutas, observações e vivências, também ficou claro que, apesar do uso de técnicas não tradicionais, como o viveirismo, a compostagem, a adubação verde e o uso de biofertilizantes, trazidas pelos técnicos do IECAM, o saber guarani continua sempre sendo 
ressaltado e valorizado por eles, conforme karaí Adolfo, da Aldeia da Varzinha: "Precisamos falar muito com a sabedoria do índio guarani"; Felipe Brizoela, da Aldeia Pindoty: "O branco acredita no papel, nós no coração. Não nos criamos pelo papel, mas pelo espírito sagrado"; e cacique Cirilo, da Aldeia da Lomba do Pinheiro:

O conhecimento tradicional é milenar, é um valor que a gente tem, é sabedoria. É o nosso futuro, porque nossas crianças continuam aprendendo a medicina, a conviver com os parentes, a conviver com esse sistema cultural (Entrevista com Cirilo Morinico, cacique da Teko'a Anhetenguá, 2016).

Algumas observações indígenas se referem ao projeto inclusive como um estímulo para retomar e dar continuidade a atividades tradicionais da cultura mbya guarani que estavam sendo pouco utilizadas:

\begin{abstract}
Este novo começo é na verdade uma retomada de questões que estavam um pouco esquecidas, como a troca de sementes, de alimentos e de remédios, o plantio de árvores e o cultivo de roças nas aldeias. A mata nativa tem tudo o que precisamos e o projeto é para nós esse novo começo. O projeto está trazendo as coisas antigas de volta (Entrevista com José Brizoela, cacique da Teko'a Nhuuporá, 2011).
\end{abstract}

Estas constatações são relevantes, pois a simples absorção de técnicas não indígenas, sem a devida valorização da sua própria cultura, poderia ser considerada como uma interferência negativa na tradição indígena, uma imposição com características dominadoras, ainda com traços colonialistas. Mas em uma concepção de dinamismo cultural, esta conjunção entre diferentes culturas pode deixar de ser considerada como uma interferência, como algo negativo que está "aculturando" os indígenas e prejudicando a continuidade de sua tradição, mas como um processo que vem trazendo ideias importantes para a situação atual das aldeias, ao mesmo tempo em que procura respeitar o tempo e a cosmologia indígena, oferecendo incentivo para a valorização e a continuidade dos saberes tradicionais.

Autores como Menezes e Bergamaschi (2009) refletem sobre o fato da cosmologia guarani não ser estática, e dos indígenas também se 
Stumpf et al - Reflexões a partir de registros de percepções dos mbya guarani sobre...

modificarem, como todas as sociedades, estando sempre se movimentando e se recriando. Este movimento contínuo de recriação é relatado por Claudino (2010), referindo-se aos povos indígenas kaingang como uma sociedade que vem se transformando ao longo do tempo, influenciada pela cultura envolvente, da mesma maneira como as outras sociedades mudam. No entanto, os povos indígenas conseguem manter uma lealdade à sua identidade cultural e étnica, o que constitui uma característica de sua dignidade pessoal. Este autor, representante indígena kaingang, ressalta que para preservar a lealdade a este modo de ser, com sua cultura e ritualística e a manifestação de heranças tradicionais muito antigas, a terra é um fator essencial e prioritário, através do qual conseguem manter seu modo de vida, plantando seus alimentos, coletando e produzindo artesanato, se adaptando às transformações econômicas.

Neste sentido, uma intervenção com relação a técnicas agroecológicas, quando necessário, pode se transformar em um fator de contribuição para a melhoria da terra, a qual se constitui em elemento fundamental para a continuidade do modo de vida tradicional de cada etnia. É importante ter a clareza desta integridade, esta lealdade à identidade cultural e étnica, que é mantida na tradição indígena, e o reconhecimento de que os indígenas possuem a liberdade de escolha e somente vão optar por determinada tecnologia se quiserem, no momento e na forma que desejarem.

Houve situações, durante o projeto, em que alguns guarani aceitavam determinadas propostas, mas não davam continuidade, às vezes por não quererem realmente e terem dificuldade de dizer não, conforme a explicação do cacique Miguel, da aldeia de Riozinho, ou outras vezes porque algo não funcionou do modo como gostariam. Em ambos os casos destaca-se a importância de se estar sempre alimentando o diálogo e a confiança para que possam expressar espontaneamente o que querem, quando não possuem mais interesse em alguma atividade, ou não gostam da forma como foi proposta. De acordo com o pensamento do cacique Cirilo, "primeiro tem que experimentar o que vem de fora, e depois aceitar o que vai ser importante, o que vão querer realmente".

É importante considerar a complexidade deste tipo de relação, 
que envolve obstáculos relacionados com várias questões, como diferenças linguísticas e culturais, diversidade de opiniões individuais, e mudança de ponto de vista ao longo do tempo. Echeverry (2008) relata a existência de dificuldades relativas à diversidade de interesses e expectativas envolvidas em projetos que reúnem diferenças institucionais e culturais. O autor desenvolve uma reflexão sobre 0 diálogo de saberes, não somente como uma troca de conhecimentos, ideias, discursos, significados, mas como uma relação entre sujeitos socialmente situados, que possuem diferentes visões de mundo, interesses, ideais, convicções e hábitos. Destaca, ainda, a importância de que esta ciência das relações, este saber dos diálogos seja considerado como um saber manter alianças e relações fecundas, não significando somente o saber do outro e o saber sobre o outro, mas saber reconhecer e respeitar o outro como sujeito, contemplando, ainda, o processo de saber de si, de se conhecer.

Este autoconhecimento pode contribuir para outro elemento da interculturalidade, o qual é abordado por Canclini (2007): o como aprendemos a ser interculturais ao nos relacionarmos uns com os outros, em um processo dinâmico que inclui relações de entrelaçamento, trocas, empréstimos e conflitos, nas quais os diferentes são o que são. Esta relação não é um caminho pronto, simples e harmonioso, sem dificuldades. Se trata de uma aproximação que precisa ser construída e cuidada, com muita sinceridade, flexibilidade e abertura para mudanças, incluindo diálogos, negociações e reflexões, podendo resultar em vínculos de amizade e companheirismo, com transformações e aprendizagens mútuas.

Kush (2009) coloca, como exemplo da dificuldade de integrar diferentes modos de pensar, uma situação de seca em que é oferecida uma solução tecnológica para os indígenas, a bomba hidráulica, mas a qual o ancião rejeita por preferir a solução tradicional ritualística. Um exemplo semelhante ocorreu durante o desenvolvimento da atuação do IECAM, com relação à primeira vez em que foi sugerida a construção de um viveiro para a produção de mudas e o posterior plantio nas aldeias, em que a resposta guarani foi de que eles não iriam plantar, pois Nhanderu é que planta as árvores. No entanto, com a continuidade da convivência e dos diálogos entre a coordenadora do Instituto e os 
indígenas, chegou um momento, após um período de dois anos, em que eles decidiram que poderiam "ajudar Nhanderu, plantando árvores". E durante o desenvolvimento da atuação houve uma fala importante do cacique José neste sentido: "Este projeto não é dos humanos, é de Nhanderu. Nhanderu sempre trazia sementes, e agora está trazendo através do projeto".

O cacique José se refere, ainda, ao fato de sempre rezar pelos juruá que trabalham com eles, para que possam ter saúde e conseguir vencer as dificuldades para a continuidade dos trabalhos. Há aqui um entrelaçamento entre uma visão cosmológica guarani e uma solução ocidental proposta por uma instituição. Albert (1995), referindo-se ao discurso político indígena yanomami, o descreve como uma mistura entre categorias do pensamento ocidental e uma reelaboração cosmológica de fatos relacionados com este encontro intercultural.

Mas o discurso de alguns representantes guarani mostra um pensamento contrário à ideia de "mistura de pensamento", conforme, por exemplo, a fala de Jorge Morinico: "é como azeite na água, não se misturam". A opinião de Cirilo trazida a seguir explica mais detalhadamente esta ideia:

A cultura indígena e a ocidental não se misturam, ficam separadas, cada uma tendo seu limite. Tem que reconhecer as diferenças e respeitar. É muito difícil, dois mundos com visões diferentes. É difícil o branco entender a cultura indígena. Tem que entender e sentir com a alma, não adianta pelos livros. Pra mim também é importante e difícil entender o sistema ocidental (Entrevista com Cirilo Morinico, cacique da Teko'a Anhetenguá, 2016).

De modo semelhante, Luciano (2011, p. 280), ao se referir aos povos indígenas do Alto Rio Negro, sugere o uso da noção de complementaridade, ao invés do hibridismo que indica um mescla ou combinação entre culturas, pois o que ocorre na região é uma "articulação, agregação de novos saberes e práticas". Conforme o autor, isso não significa uma fusão de horizontes, mas uma complementaridade de saberes, importante para a relação entre culturas e para novas construções de pensamentos e visões. 


\section{Considerações finais}

As reflexões, com base em percepções mbya guarani, mostram a importância do diálogo intercultural em ações socioambientais com comunidades indígenas, através de construções conjuntas, de forma participativa, com base na identificação de demandas comunitárias, proporcionando a complementaridade entre saberes da cultura indígena e ocidental. Esta abordagem dialógica, participativa, intercultural e de envolvimento comunitário precisa permear todas as fases dos projetos, oferecendo perspectiva de continuidade a médio e longo prazo, junto a instrumentos que favoreçam uma crescente autonomia.

No entanto, é importante que a relação seja fundamentada em uma proposta de interculturalidade crítica, com o olhar atento quanto à histórica supervalorização do saber ocidental, intelectual, científico e técnico em detrimento aos conhecimentos tradicionais indígenas. A concepção deste tipo de trabalho deve ser direcionada para uma simetria de saberes, incentivando a valorização dos conhecimentos tradicionais, em uma perspectiva de aprendizagem mútua entre diferentes culturas. Ao mesmo tempo em que proporciona valorização e aprendizagem com relação a ideias e valores mais simbólicos, artísticos, intuitivos, afetivos e comunitários, a atuação pode proporcionar acesso dos indígenas a processos de capacitação relativos aos conhecimentos ocidentais, conforme seus interesses, e com a devida certificação.

Assim, este tipo de ação socioambiental não se manifesta na forma de uma interferência cultural, e sim em uma perspectiva de interaprendizagem, permitindo uma complementaridade de pensamentos, proporcionando contribuições para a revitalização de saberes tradicionais e para o acréscimo de outros conhecimentos, conforme seus interesses, necessidades e conveniências. No exemplo trazido por esta pesquisa, muitos saberes e práticas tradicionais de uso e manejo da biodiversidade foram integrados a técnicas ecológicas ocidentais, como viveirismo, agroecologia, compostagem e reciclagem, compondo estratégias dinâmicas, cujo uso vai se modificando ao longo do tempo, podendo alcançar importantes resultados, especialmente para a segurança alimentar e recomposição ambiental das áreas. 
Para os profissionais não indígenas, esta relação pode trazer profundas aprendizagens e transformações, através da abertura para outras formas de ver, pensar, sentir, agir e se relacionar. A sabedoria mbya guarani constitui um conjunto de saberes, valores e práticas ecológicas, comunitárias, simbólicas, artísticas, junto a um modo peculiar de transmissão entre gerações, que podem contribuir para reflexões importantes em diversas áreas, como educação, ecologia e saúde. A sociedade ocidental, na complexidade de suas relações e negociações, vive uma dinâmica de contínua transformação, absorvendo saberes de outras culturas, conforme interesses. As crises multidimensionais da atualidade mostram a necessidade de renovações para as quais pode haver importantes contribuições nos diálogos interculturais.

A noção de interculturalidade para representantes desta etnia, conforme a pesquisa, não significa uma mistura de culturas, mas uma complementaridade, que ocorre através do exercício mútuo de convivência, respeito e aprendizagens recíprocas. Esta relação também implica no enfrentamento das dificuldades que fazem parte do processo, envolvendo ritmos distintos de vida e modos diversos de lidar com o tempo e com recursos, os quais precisam ser respeitados.

\section{Referências bibliográficas}

ALBERT, B. O ouro canibal e a queda do céu: uma crítica xamânica da economia política da natureza. Série Antropologia, Brasília, n, 174, p. 1-33, 1995.

CANCLINI, Néstor Garcia. Diferentes, desiguais e desconectados: mapas da interculturalidade. Rio de Janeiro: UFRJ, 2007.

CLAUDINO, Zaqueu Key. Educação indígena em diálogo. Pelotas: Editora Universitária/UFPEL, 2010. (Cadernos Proeja II - Especialização - Rio Grande do Sul. v. II).

ECHEVERRY, Juan Alvaro. Diálogo de saberes y meta-saberes del diálogo: uma perspectiva amazônica. Estudos Sociales Comparativos, v. 2, n. 1, p. 16-45, 2008.

ENGERS, Maria Emília Amaral. Pesquisa educacional: reflexões sobre a abordagem etnográfica. In:

(Org.). Paradigmas e metodologias de pesquisa em 
educação: notas para reflexão. Porto Alegre: EDIPUCRS, 1994. p. 168-180.

FEHLAUER, Tércio. A experiência do curso "Agroecologia em Terras Indígenas": traçados e proposições para um debate sobre aprendizagem técnica intercultural e emancipatória. Retta, Rio de Janeiro, v. 1, n. 2, p. 105-121, 2010.

FUNDAÇÃO NACIONAL DO ÍNDIO. COORDENAÇÃO GERAL DE GESTÃO AMBIENTAL (Org.). Plano de Gestão Territorial e Ambiental de Terras Indígenas: Orientação para Elaboração. Brasília: FUNAI, 2013.

GASCHÉ, Jorge. La motivación política de la educación intercultural indígena y sus exigencias pedagógicas. Hasta dónde abarca la interculturalidad? In: BERTELY, María; GASCHÉ, Jorge; PODESTÁ, Rossana (Org.). Educando en La diversidad cultural: Investigaciones y experiencias educativas interculturales y bilíngües. Quito-Ecuador: Ediciones Abya-Yala, 2008. p. 279-367.

GOMIDE; Maria Lucia Cereda; SANTOS, Alex Mota dos. Registros das Terras Indígenas de Rondônia por meio de mapas mentais. Revista Cultura e Extensão USP, São Paulo, n. 13, p. 55-63, 2015.

HERCULANO, E. F. Educação ambiental como contribuição para construção de valores: práticas e saberes do educador em uma comunidade indígena Terena. Revista Eletrônica de Ciências da Educação, Campo Largo, v. 6, n. 2, 2007.

KUSCH, Rodolfo. Obras completas: tomo II. Córdoba: Editorial Fundación Ross, 2009.

LEFF, Enrique (Org.). A complexidade ambiental. São Paulo: Cortez, 2003.

Ecologia, capital e cultura: a territorialização da racionalidade ambiental. Petrópolis: Vozes, 2009.

LIMA, Artema; SATO, Michèle. Educação Kaiabi: um diálogo entre o currículo e os projetos de sustentabilidade nas aldeias. Terceiro Incluído, Goiânia, v.1, n.2, p. 1-21, 2011.

LUCIANO, Gersem José dos Santos. Educação para o manejo do mundo: entre a escola ideal e a escola real. Os dilemas da educação escolar indígena no alto rio Negro. 2011. 369 f. Tese (Doutorado em Antropologia Social) - Programa de Pós Graduação em Antropologia Social, Universidade de Brasília, Brasília, IF, [2011].

MENEZES, A. L. T.; BERGAMASCHI, M. A. Educação ameríndia: a dança e a escola Guarani. Santa Cruz do Sul: EDUNISC, 2009.

OLIVEIRA, Luiz Fernandes de; CANDAU, Vera Maria Ferrão. Pedagogia decolonial e educação antirracista e intercultural no Brasil. Educação em Revista, Belo Horizonte, v. 26, n. 1, p. 15-40, 2010. 
REPETTO, Maxim. Os Sentidos das Fronteiras na Transdisciplinaridade e na Interculturalidade. Textos \& Debates, Boa Vista, n. 22, p. 13-30, 2012.

ROCHA, G.; TOSTA, S. P. Antropologia \& Educação. Belo Horizonte: Autêntica Editora, 2009.

SILVA, Solange Pereira da. Indigenismo alternativo: no compasso da educação intercultural entre os kanamari do médio Juruá - AM. 2007. 137 f. Dissertação (Mestrado em Educação) - Programa de Pós-Graduação em Educação, Universidade Federal de Mato Grosso, Cuiabá, MS, [2007].

SILVA, Adeilson Lopes da; CABALZAR, Aloisio. As escolas indígenas e o manejo ambiental no alto rio Negro. In: CABALZAR, Flora Dias (Orgs.). Educação escolar indígena do Rio Negro: relatos de experiências e lições aprendidas. São Paulo: Instituto socioambiental; São Gabriel da Cachoeira, AM: Federação das Organizações Indígenas do Rio Negro, 2012. p. 400-407.

SILVA, G. F. da.; NORNBERG, M. Proposições para o diálogo intercultural: movimentos necessários. In: SILVA, G. F. da; PENNA, R.; CARNEIRO, L. C. da C. (Orgs.). RS índio: cartografias sobre a produção do conhecimento. Porto Alegre: EDIPUCRS, 2009. p. 124-129.

SOUSA SANTOS, Boaventura de; MENESES, Maria Paula G.; NUNES, João Arriscado. Para ampliar o cânone da ciência: a diversidade epistemológica do mundo. In: Boaventura de Sousa Santos (Org.). Semear Outras Soluções: os caminhos da biodiversidade e dos conhecimentos rivais. Rio de Janeiro: Civilização Brasileira e Ministério da Cultura, 2005. p. 21-45.

TOP'TIRO, Hiparidi; GOMIDE, Maria Lucia Cereda; LIMA; Daniela Batista de. Capacitação dos Agricultores e Agricultoras Xavante no Uso e Conservação da Agrobiodiversidade no Cerrado. In: VERDUM, Ricardo; ARAUJO, André Araujo. (Org.). Experiências de Assistência Técnica e Extensão Rural junto aos Povos Indígenas: O Desafio da Interculturalidade. Brasília: NEAD/SAF, 2010. p. 130-156.

WALSH, Catherine. Interculturalidad crítica y educación intercultural. In: VIAÑA, Jorge; TAPIA, Luis; WALSH, Catherine (Org.). Construyendo interculturalidad crítica. La Paz - Bolivia: Instituto Internacional de Integración del Convenio Andrés Bello, 2010. p. 75-96.

ZANIN, N. Z. Aspectos simbólico-culturais e continuidade das construções MbyáGuarani. In: SILVA, G. F. da; PENNA, R. \& CARNEIRO, L. C. da C. (Org.). RS índio: cartografias sobre a produção do conhecimento. Porto Alegre: EDIPUCRS, 2009. p. 179-193. 
Stumpf et al - Reflexões a partir de registros de percepções dos mbya guarani sobre...

Recebido em: 09/04/2017 * Aprovado em: 01/06/2017 * Publicado em: 30/06/2017 